\title{
The Role of Education and Knowledge about Aging in Creating Young People's Attitudes to the Elderly
}

\author{
Jana Goriup - Danijela Lahe*
}

\author{
Received: June 29, 2017; received in revised form: March 10, 2018; \\ accepted: March 13, 2018
}

\begin{abstract}
:
Introduction: With the intensive growth in the number of older people and prolonged life span in the contemporary postmodern society, it has become increasingly important to build positive intergenerational cooperation and promote education on aging and older people, especially between younger and older generations. That is why the authors, on the basis of empirical research and scientific literature, examined knowledge about aging among young people and the connection between knowledge about aging and the formation of negative attitudes towards older people.

Methods: The study involved 609 secondary school students aged 15 to 19 years. Results: The survey results showed that only one-fifth of the young population has good knowledge about aging. The relationship between knowledge about aging and ageism is negative, which means that young people with less knowledge about aging often have a negative attitude towards older people.

Conclusions: Based on the obtained results, the authors underline the importance of integrating gerontology content in all stages of education.
\end{abstract}

Key words: education, knowledge about aging, attitude to the elderly, ageism, gerontophobia, youth, elderly.

\section{Introduction}

In the last few decades, life expectancy has been intensively prolonged. This prolongation in the Western contemporary societies, especially in Europe, led to large and unexpected structural changes in the population. The number of elderly people is growing intensively, while there is a decrease in the number of children and adolescents. According to the UN (United Nations, 2015), in 1980, there was 6.4\% of the population older than 65 years. By 2015, their number had increased to 10\%. In the coming decades, an even greater disparity is expected, it is projected that in 2050 it will achieve $20.5 \%$. Slovenia is confronted with circumstances similar to the ones found in the modern Western societies, mainly due to persistently low fertility and increased longevity. While the proportion of newborn babies is being reduced, the share of the elderly is growing. The forecast is that the most growing number of people is the number

\footnotetext{
* Jana Goriup, Alma Mater Europaea Maribor, Maribor, Slovenia; jana.goriup@guest.um.si

Danijela Lahe, University of Maribor, Faculty of Arts, Maribor, Slovenia; danijela.lahe@um.si
} 


\section{Acta Educationis Generalis \\ volume 8, 2018, issue 1}

of people older than 85 years of age, and it should not be ignored. This is also the part of the population that needs a lot of social and medical care.

Thus, as never before, we are faced with an (im)balance between the young, middle and older generations regarding their number. Already Baldock (1993, as cited in Rener, 1997, p. 41) wondered whether we are, and how we are, as a society, prepared for the old age and aging society, as both the aging and old age, like childhood and youth, are largely a social construct, regulated by institutional processes. Dremelj (2003, p. 149) points out that the particular circumstances of modern society promote individualization, also chipping of the social family networks, relatives and friends. Above all, in developing young people's attitudes to the elderly population, solidarity within the family and the context of family life have at least two important implications. The first is the issue of care for the elderly, which focuses on the relationship between the state and the family, especially when it comes to their division of responsibilities for older people, since informal family care for the elderly also covers the sphere of family life and gender division of labour: care for the elderly, family and kinship ties, are all still considered typical women's roles. The second implication relates to the fact that older people play an important role in "providing assistance" in family life, primarily in providing child care. Thus, aging of the population plays a key role in the intergenerational relationships, relationships within the family, as well as the cooperation between generations (Hvalič Touzery, 2009, pp. 54-57).

Intensive aging and longevity requires the creation of new relationships between generations and a new type of positive intergenerational cooperation especially between the younger and the older generation. Social changes, including modernization, have not only resulted in a longer life, but also changed the attitude towards older people. Even to the extent that the elderly have become a social problem, the target of ageist behaviour of the younger generation, and the subject of gerontophobia (Goriup, Čagran, \& Krošl, 2015). Beck (2007) in his "risk society" theory, realized that the transition to an industrial society created a society prone to productivity, and in accordance with its own interests, it creates the image of older people being not independent, but dependent on others, unproductive and inactive members of the society. The prevailing stereotypes about old age create a general negative attitude towards age in the society and has an influence on the perception of old age, which results in low self-esteem. Therefore, the expectations and requirements are low as well.

Although people are ageing, and we are also getting older (if we live long enough), this completely natural process has become a taboo. Older people are stereotyped with ageist and paternalistic views. When we talk about the old age as a taboo, we should not overlook the problem of ageism. The impact of ageism started to grow in the mid-80s of the last century, at a time when the Americans developed a set of prejudices and discrimination against older people (Palmore, 1998, p. 4). Ageism was first defined Butler as a "process of systematic stereotyping and discrimination against older people". The author noted that ageism consists of three constituent elements: prejudice against age, aging and older people; discrimination against older people, especially in the working environment, as well as in the social environment; institutional policies and procedures that perpetuate stereotyped beliefs about older people, and reduce opportunities for older generations to live satisfactory life, diminishing their personal dignity (Butler, 2005). Ageism is definitely discrimination based on calendar age, which determines an individual's ability and their role. It means stereotyping and 


\section{Acta Educationis Generalis \\ volume 8, 2018, issue 1}

discrimination against older people simply because they are old. While Pečjak (2007) points out that ageism is deeply rooted in the human spirit, even though a lot of people are not aware of it, Schirrmacher (2007) adds that older people are not only discriminated by the younger generation, but also older people have a negative attitude towards the older.

Palmore (1998, p. 4) has expanded the definition of ageism, as he understands it "as any prejudice or discrimination against or in favor of any age group"; i.e. judging people based on age, and at the same time, highlighting its negative and/or positive aspects. Some authors (e.g. Butler, 2005) even conclude that ageism is a frequent and widespread phenomenon of the post-modern society, even among the young generation. Angus and Reeve (2006) add that despite the global aging of population and the introduction of positive terms such as "successful aging" and "active aging", ageism is in the 21 st century still "a widespread and widely accepted and largely ignored" social phenomenon, which is very complex and hard to deal with, and difficult to understand.

Some authors (e.g. Palmore, 1998) find the reasons for the increase of ageism in the intensive growth of elderly population in the Western societies. Most people are becoming increasingly worried about the rise of the older generation in comparison with the rest of the population. The increasing number of old people increases the concern for the issues of retirement, income security, and provision of health care to this growing and vulnerable social group. Besides a growing political concern about ageism, there are also personal consequences of this socially undesirable process (demoralisation, loss of self-esteem, inactivity, physical and mental decline), therefore it becomes an important ethical and social issue. Not only is the age in postmodern society tabooed, but there could also be felt gerontophobia, which often causes feelings of anger towards aging, and fear and insecurity of individuals over their own aging and (even) hostility to older people. Even the elderly themselves often deny that they are old.

Most of the older people find it difficult to cope with their age due to the prevailing stereotypes and ageism in society. Instead of fighting against stereotypes, they prefer to live the lifestyle of the younger ones, as long as it is possible. Laymen's perceptions are full of stereotypes, presenting the older population as a uniform and homogeneous social group that is getting ill, completely dependent on other social groups, and is shortly before their death. Stereotypes and beliefs about aging affect not only the behaviour and handling of the elderly but may have a significant impact on an individual's experience of aging (Ward, 1979, pp. 128-156). Ward (1979) also believes that the individual state of health has a key role in experiencing the fear of aging and the elderly, with a specific reference to self-esteem. Also, because self-esteem in the old age is a complex phenomenon which depends on the interaction between personal integration, the self, as perceived by others, and socially constructed image of the old persons.

For prevention of ageism, but also maintaining a positive attitude towards older people and developing a positive acceptance of own aging, attitudes and knowledge regarding aging, especially in the case of children and young people, but also in other age groups, must be positive and without stereotypical views on the old age and older people.

To prevent ageism, different authors investigated the relationship between the knowledge about aging and the attitude towards the elderly. The findings of their studies are not consistent, since, on one hand, some authors found that knowledge has no direct influence on the attitude to the elderly and Palmore (1998) noticed a weak correlation between knowledge about aging and the level of education. On the other hand, the 


\section{Acta Educationis Generalis \\ volume 8, 2018, issue 1}

research conducted by Alford et al. (2001), Allan and Johnson (2009, p. 9), Braithwaite (2002), Butler (2005), Damron-Rodriguez, Funderburk, Storms and Solomon (2006, p. 457), O’Hanlon, Camp and Osofsky (1993, p. 762), Stuart-Hamilton and Mahoney (2003) found out the exact opposite: a better understanding of the aging contributes to a more positive attitude towards older people. Braithwaite (2002, p. 331) adds that an appropriate educational approach with guidelines for the life quality improvements at every stage of the aging process, could help solving problems with aging, and help reduce the fear of aging throughout the life. Therefore, he suggests an appropriate model for education on aging and prevention of ageism with an accent on the improvement of inter-generational understanding and relationships. Even Alford et al. (2001) assume that the knowledge about aging itself is associated with attitudes towards aging and is considered as one of the most effective methods of changing the attitudes among individuals.

Due to the global aging population, there is also a growing need for qualified individuals with relevant knowledge about aging and thorough understanding of the aging process (Gellis, Sherman, \& Lawrence, 2003). Therefore, Anderson (1999), Kaya et al. (2014) and Olson (2007) estimate that education on aging should be incorporated into the school curriculum at all levels of education, as it was already confirmed by the studies of Knapp and Stubblefield (2000), O'Hanlon and Brookover (2002), O'Hanlon, Camp and Osofsky (1993) and Stuart-Hamilton and Mahoney (2003), who all explored the changes in knowledge and attitudes towards the elderly as a result of curriculum interventions. The results of those studies showed a positive change in the knowledge and attitudes towards the elderly as a result of the participation in a course or workshop focused exclusively on the issues related to the elderly. The inclusion of such content in the curricula could improve both the knowledge about aging and older people, as well as the attitudes towards them, since we note that ageism (also) might be the consequence of a lack of understanding of individual aging.

Although, there are indications that the stereotypes about aging and older people can be reduced through education, it was found out that there is another effective way of combatting stereotypes, prejudices and discriminatory behaviour (besides other social factors), which is the establishment of permanent links between individuals from different social groups. This means that for the elimination of ageism, prejudice and stereotypes, it is of an essential importance to establish a stable and continuous interaction between the generations. As observed by Hagestad and Uhlenberg (2005), intergenerational programs which connect young and older people help resolve those adverse social phenomena. Also, appropriate early contacts between the children and the elderly can prevent the development of stereotypes and prejudices towards the elderly. As underlined by McGuire and Mefford (2007), it is always easier to learn than re-learn. Thus, it is easier to change the already adopted ageist observations in children when they are not so deeply rooted.

\section{Methods}

The primary purpose of the research is to consider the characteristics of knowledge about aging among young people. At the same time, we want to determine whether there is a negative correlation between knowledge about aging and attitudes toward elderly and also fear of aging (gerontophobia). We were also interested in the impact of the 


\section{Acta Educationis Generalis \\ volume 8, 2018, issue 1}

gerontological content included in the curriculum in shaping the relationship between the youth and elderly ${ }^{1}$.

\subsection{Participants}

The non-randomized convenience sample included 1228 adolescents in Maribor, aged 15 to 29 years; i.e. 612 secondary high school students and 616 university students; $57.1 \%$ female and $42.9 \%$ male.

The respondents were selected on the basis of probability. Due to the lack of cooperation and other "mistakes", the demographic characteristics of the selected sample slightly deviate from the characteristics of the target population. The representativeness of the sample was guaranteed on the basis of gender. Based on the data obtained before and after weighting shown in Table 1, we can assume that we chose a relatively appropriate sample. Deviations from the sample of the target population are relatively small, which was also confirmed by a small lag between weights (minimum weight is 0.76 ; maximum 1.72).

Table 1

A comparison of the characteristics of youth by gender with weighted case and nonweighted case

\begin{tabular}{|c|c|c|c|}
\hline & $\frac{\text { The population of }}{15-19 \text { years old }}$ & $\frac{\text { The selected sample }}{\text { without weights }}$ & $\frac{\text { The selected model }}{\text { with weights }}$ \\
\hline Male $(\%)$ & 43 & 25 & 42.9 \\
\hline Female (\%) & 57 & 75 & 57.1 \\
\hline Total & 100 & 100 & 100.0 \\
\hline
\end{tabular}

\subsection{Instruments}

For the measurement of ageism we used 11 variables from the Fraboni Scale of Ageism (Fraboni et al., 1990; Rupp et al., 2005), namely: "A lot of older people are mean and accumulate their money and property"; "Many elderly people cannot be trusted to take care of the babies"; "Many older people are happier when they are in the company of people of their age"; "Many older people have poor personal hygiene"; "Teen suicide is more tragic than suicide among the elderly"; "Sometimes I avoid eye contact with older people"; "The best is that older people live there where they do not disturb anybody"; "It is sad to hear about suffering of older people in the Slovenian society"; "Older people should be encouraged to express their political points of view"; "Driving license should not be renewed to most elderly people!" "I would rather not live with an older person" and "Older people do not need a lot of money to meet their needs." The respondents expressed their agreement or disagreement with each of the 11 statements on the fouritem scale $(1=$ strongly disagree to $4=$ totally agree $)$. The adequacy of this composite variable was confirmed to have a satisfactory level of internal consistency $(\alpha=0.70)$.

Fear of ageing was measured by a standardized unit of measure The Anxiety about Aging Scale (AAS) (Lasher \& Faulkender, 1993). The respondents were asked to

\footnotetext{
${ }^{1}$ The elderly person is defined as a person aged 65 years and older.

${ }^{2}$ We gain the data at the Ministry of education, science and sport.
} 


\section{Acta Educationis Generalis \\ volume 8, 2018, issue 1}

express their agreement or disagreement with the statements on a five-item Likert Scale (1 - strongly disagree, 2 - disagree; 3 - neither agree nor disagree; 4 - agree; 5 strongly agree). The scale measured the level of fear of old people, fear of loss, psychological concerns and fear of physical appearance. For the purposes of the questionnaire, we used only 12 of the 20 claims (variables) from the source, but we nevertheless ensure the measurement of all components of the fear of aging. On the basis of factor analysis there are formed three factors, with a value of (eigenvalues) more than one, which total of explaining $61.99 \%$ variance.

Basis of the knowledge measurement about aging is Palmor's "Facts on Aging Quiz" (Palmore, 1977), containing 25 (correct and incorrect) statements, and measures actual level of knowledge about aging. Measurement scale was modified in accordance with the needs of the Slovenian population, out of which 10 relevant arguments were selected. For each correct answer, respondents get one point, so they can collect a maximum of 10 points. It was assumed that respondents who collected from 0 to 4 points have "poor" knowledge about aging; those with 5 to 7 points have 'average' knowledge, and respondents with 8 to 10 points, good knowledge about aging.

As correct answers are considered: "The aging brings some deterioration of all five senses (sight, hearing, taste, touch, and smell)", "Older people usually need more time to learn something new", "Elderly are prone to react slower than younger", "More than $15 \%$ of the Slovenian population is older than 65 years", and "Average net pension is less than $€ 570$ in the year 2014, which is below the poverty line (as defined by the Slovenian government)". All other claims are incorrect. Internal consistency of the measurement scale is low $(\alpha=0.62)$, but still satisfactory.

\subsection{Procedure}

Data were collected through online survey (1KA). Measuring instrument was rationally and empirically tested and supplemented and amended in accordance with the findings. Before sampling, we sent principals of the secondary schools in Maribor a letter of consent and asked them for help in motivating students to complete the online surveys. School counsellors provided a link to e-classrooms, where students filled out online surveys.

We are also following the classic post applied for aid, most faculties in Maribor. Vicedeans for student ${ }^{3}$ questions were provided by an online survey for students at the common email addresses sections. They also helped us in carrying out the survey to help some higher education teachers and collaborators who have made it possible for us to have the students fill out an online survey in the context of seminar lectures or tutorials. We used quantitative survey research method, which contained questions of closed and open type and Likert Scale. The questionnaire was composed of four sets of questions relating to ageism, knowledge about aging, fear of aging and socio-demographic data.

\subsection{Statistical Analyses}

Data were statistically analyzed in accordance with the purposes and research predictions using statistical software package SPSS 21. Quantitative data analysis was based on descriptive statistics (frequencies, means, standard deviations), and bivariant

\footnotetext{
3 Vice-dean student is a student representative, who is also president of the student council of the Faculty and the only member of the Board of the Faculty for the students.
} 
analysis (Mann-Whitney U-test and Spearman's Correlation). Internal consistency of the scales was measured by Cronbach's Alpha.

\section{Results}

Firstly, the extent of knowledge about aging among the surveyed adolescents was determined. The data in Figure 1 show that only $26.3 \%$ of the respondents have "good" knowledge on aging, most of them (68\%) have "average" knowledge about aging and $5.7 \%$ "poor" knowledge on aging.

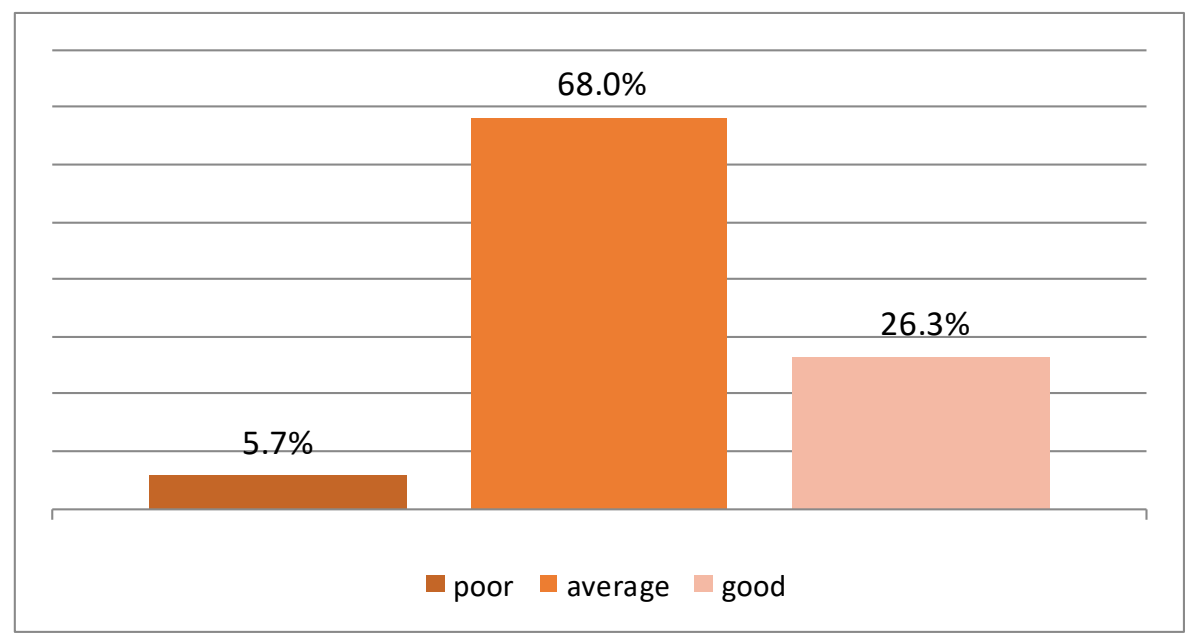

Figure 1. Scope of knowledge about aging among adolescents.

Regarding the quantity and characteristics of knowledge about aging among young people, unlike some previous studies (Allan \& Johnson, 2009; Palmore, 1998; Scott, Minichiello, \& Browning, 1998), who reported about young people's poor knowledge about the old age, we found out that the majority of surveyed young people (68\%) have an average knowledge about aging. 


\section{Acta Educationis Generalis \\ volume 8,2018 , issue 1}

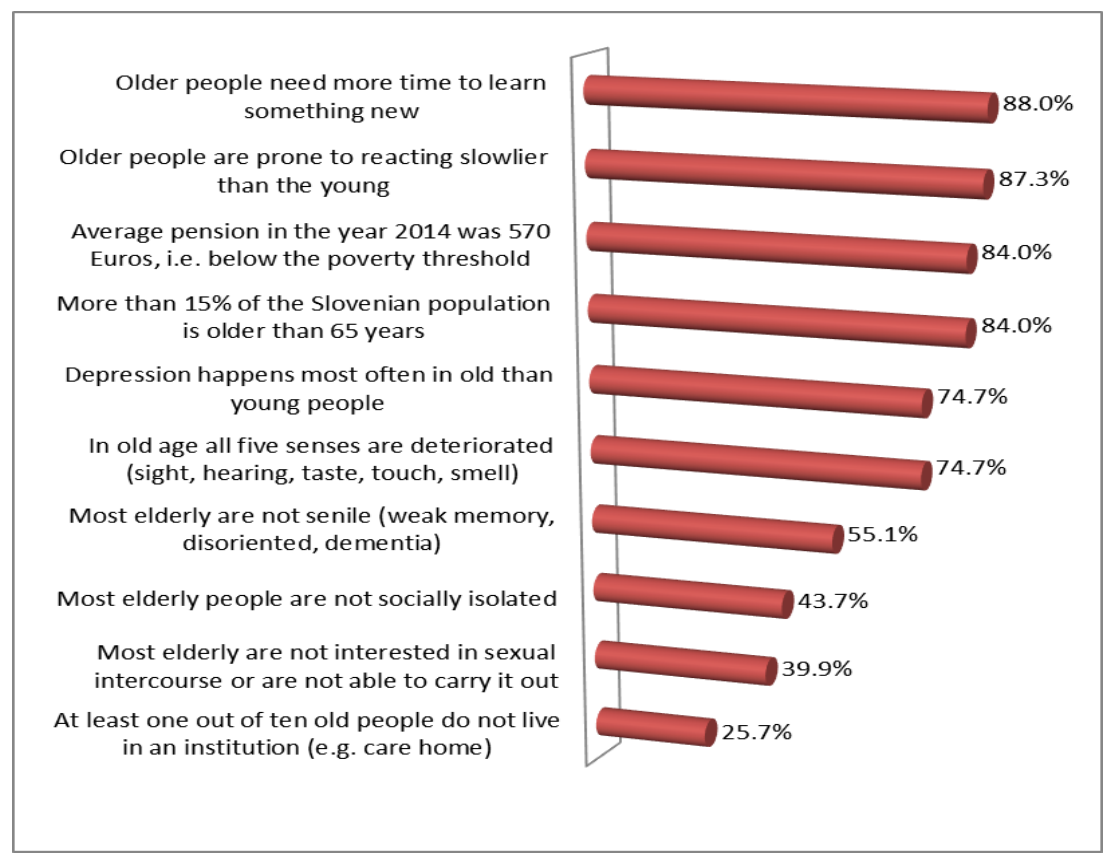

Figure 2. Proportion of knowledge of individual facts about older among adolescents.

At this point, we present the knowledge of the surveyed young people about the particular facts about the elderly (Figure 2). For better transparency, incorrect answers were recoded to correct answers.

Based on the obtained empirical data, we have found that the wrong beliefs of the surveyed high school students about the elderly relate primarily to the following statements: "At least one in ten older people lives for a longer time in an institution"; "Most older people are not interested or not able to have sex."; "Most of the elderly are socially isolated." and "Most elderly are senile.". The obtained data have to be considered in the school curriculum planning.

Regarding knowledge about aging, there are statistically significant differences between the genders $(\mathrm{U}=252353, \mathrm{p}=0.05)$; females $(\mathrm{M}=6.66, \mathrm{SD}=1.37)$ have, on average, a little more knowledge about aging than males $(\mathrm{M}=6.48, \mathrm{SD}=1.45)$. Statistically significant differences $(\mathrm{U}=252437, \mathrm{p}<0.01)$ were also found between high school students and university students; university students $(\mathrm{M}=6.71, \mathrm{SD}=1.42)$ have more knowledge compared to the surveyed high school students $(\mathrm{M}=6.47, \mathrm{SD}=1.36)$. On the basis of displayed results, we can conclude that knowledge increases with level of education and also with age (rho $=0.105 \mathrm{p}<0.01)$. The most knowledge about aging have female university students.

Spearman's coefficient showed a statistically significant negative correlation (rho $=$ $0.173, \mathrm{p}<0.01$ ) between knowledge about aging and ageism, which means that the lower the respondents' knowledge about aging is, the more often they develop negative attitudes towards older people. A statistically significant negative correlation can be found between knowledge about aging and the fear of elderly (rho $=-0.073, p<0.01$ ), 


\section{Acta Educationis Generalis \\ volume 8, 2018, issue 1}

fear of loss (rho $=-0.121, \mathrm{p}<0.01)$ and fear of physical appearance and psychological concerns (rho $=-0.134, \mathrm{p}<0.01$ ), which means that the more knowledge of aging youth have, the less often they are afraid of aging.

We were also interested in the proportion of respondents whose curriculum contained topics on age and older people. Our attempt was to find out whether there are statistical differences in ageist observations regarding the presence or absence of these topics. Utest results showed that there are statistically significant differences $(U=198299, p<$ $0.05)$ among those respondents who have incorporated content on aging and older $(\mathrm{M}=$ $6.64, \mathrm{SD}=0.75)$ and those that did not have $(\mathrm{M}=6.52, \mathrm{SD}=0.54)$.

The proportion of respondents $(33.6 \%)$ whose curriculum contained topics on age and older people during their education was lower than the proportion of respondents $(66.4 \%)$ who did not receive this kind of knowledge, because it was not included in the curriculum.

At this point we agree with the findings of Van Dussel and Weaver (2009, p. 343), who claim that young people have little opportunity to learn about the realities of aging and older people through formal teaching of gerontology content. Education should be carried out and highlighted on different levels of education, so that young people become equipped with proper knowledge, skills, resources and positive attitudes towards aging, to be able to better perceive and accept their own aging and the aging of the society as a whole.

The presumption of a negative correlation between ageism and knowledge about aging (rho $=-0.173$ ), which is partially derived from the theory of social development (Wisdom et al. 2014, p. 12), was confirmed. The lack of knowledge about the aging process among the interviewed secondary school students is significantly associated with their higher level of ageism. Similar findings were found by other researchers, for example: Allan and Johnson (2009, p. 9), Boswell (2012, p. 738), Harris and Dollinger (2001, p. 663), O'Hanlon and Brookover (2002, p. 721), Palmore (1998) and Wisdom et al. (2014, p. 17). Allan and Johnson (2009, p. 9) add that this is conditioned by the indirect effect of experiencing the fear of aging. Young people with more knowledge are less concerned about aging, which reduces their fear of aging and, albeit indirectly, reduces the negative attitude towards older people. That leads us to the conclusion that education about aging is extremely important for reducing ageism, though, not all participants in the education system are sufficiently aware of that fact. A better understanding of aging and age lowers stereotypes about older people and promote a positive attitude towards them, among children (Kroutil \& Wasyliw, 2002; McGuire, 1993) and other age groups (Aday, Sims, \& Evans, 1991; Goriup, 2014, p. 86; Meshel \& McGlynn 2004, p. 476; Olson, 2007, p. 986; Randler, et al., 2014, p. 236). Similarly, Davis-Berman and Robinson (1989, as cited in Kalavar, 2001, p. 512) suggest that the best way to change the attitude towards the elderly and aging is information dissemination on aging and age, as well as ensuring opportunities to old people to expose themselves. If this is included in the educational process early enough, it will undoubtedly reflect on merit, diversity and the benefits of the third generation. In order to prevent the reduction of positive attitudes towards the elderly, Braithwaite (2002, p. $315)$ and Randler al (2014, p. 236) propose the implementation of intergenerational educational programs, which should start in primary school, as estimated by Gilbert and Ricketts (2008, p. 582). 


\section{Acta Educationis Generalis \\ volume 8, 2018, issue 1}

\section{Conclusion}

Despite many improvements regarding the integration of older and elderly people into the society, many of them are still being faced with gerontophobia, stereotypes, age segregation, marginalization and social stigmatising. These factors enhance their helplessness, dependency and self-reliance/autonomy, as they largely affect their social inclusion or exclusion, which is conditioned by the knowledge of the young generation about aging and elderly population.

Acts of institutionalisation of the elderly in represent a product of social construction which contributes to the legitimacy of the social distance between the elderly and the young generation. Although the proportion of the elderly population have been growing rapidly and inevitably, leading to demographic aging, in the Slovenian society the cultural and social importance of aging is changing slowly, also because of myths about aging and the absence of teaching content on aging and elderly population in the curriculum. An intergenerational approach to education on aging and guidelines for improving the quality of life can significantly help overcome prejudices and reduce the fear of aging at every stage of the aging process.

The study confirmed the negative influence of ignorance about age and ageism and fear of aging, which means that the lack of knowledge about the aging process is significantly associated with a greater degree of ageism and fear of aging among young people. Since the relationship between knowledge and beliefs about aging have important implications for young people, it is necessary to include gerontology content in education (Anderson, 1999; Butler, 2005; Boswell, 2012; Kaya et al., 2014; Olson, 2007). Here, the importance and the role of intergenerational learning, which enables young people (and other members of different generations) to develop their interests and personality traits, (re)shape their values and attitudes towards themselves and others become the focus, as noted by Goriup (2014, p. 86).

According to the theory of social development (Vygotski, 1978), the basis for the development of ageism may occur very early in life, so it is important that the educational content on old age and aging is included in early childhood education. It must be added that the intergenerational programs are already underway in most Slovenian kindergartens (e.g. Program "Grandma tells"). Kindergarten educators, in cooperation with their executives, are trying to cultivate a sense of tolerance and understanding for the older generation and stimulate children's active and positive cooperation with them.

We propose the integration of educational content on age and aging in the first educational period within the lessons on Learning Environment, in the second educational period of primary school within the subject Society and in the third educational period within the subjects Biology, Patriotic and Civic Culture and Ethics. In secondary schools, we propose the integration of this content in the subjects of Sociology, Psychology and Biology, and on the tertiary level of education within the Social Sciences, Andragogy and bio-medical subjects. During their education, the young generation should have an opportunity to participate and build (quality) contacts with the older generation, as this is one of the ways leading to the establishment of education for tolerance, mutual understanding and developing a positive image of aging and older people in the society.

If we want pupils and students to receive enough knowledge about the old age and aging, we have to offer the educational programs providers (and, ultimately, the wider society) 


\section{Acta Educationis Generalis \\ volume 8,2018 , issue 1}

enough quality content from the field of the social gerontology. In doing so, we have in mind primarily higher education institutions which should take more responsibility for providing the general public with more detailed technical information on aging and elderly population, and, ultimately, for the implementation of a greater share of gerontology content and the possibility of intergenerational cooperation, particularly between the younger and older population.

\section{References}

Aday, R. H., Sims, C. R., \& Evans, E. (1991). Youth's attitudes toward the elderly: The impact of intergenerational partners. Journal of Applied Gerontology, 10(3), 372384.

Alford, C. L., Miles, T., Palmer, R., \& Espino, D. (2001). An introduction to geriatrics for first-year medical students. Journal of the American Geriatrics Society, 49(6), 782-787.

Allan, L. J., \& Johnson, J. A. (2009). Undergraduate attitudes toward the elderly: The role of knowledge, contact and aging anxiety. Educational Gerontology, 35(1), 114.

Anderson, T. B. (1999). Aging education in higher education: preparing for the $21 \mathrm{st}$ century. Educational Gerontology, 25(6), 571-579.

Angus, J., \& Reeve, P. (2006). Ageism: a threat to "aging well" in the 21 st century. Journal of Applied Gerontology, 25(2), 137-152.

Baldock, A. (1993). Old Age. In R. Dallos, \& E. McLaughin (Eds.), Social problems and the Family. London.

Beck, U. (2007). Generation Global. Frankfurt am Main: Suhrkamp.

Braithwaite, V. (2002). Reducing ageism. In T. Nelson (Ed.), Ageism: Stereotyping and Prejudice against Older People (pp. 311-337). Cambridge, MA: MIT Press.

Boswell, S. S. (2012). Predicting trainee ageism using knowledge, anxiety, compassion and contact with older adults. Educational Gerontology, 38(11), 733-741. Retrieved from http://web.a.ebscohost.com.ezproxy.lib.ukm.si/ehost/pdfviewer/ pdfviewer?sid=bced316f-666b-4bde-bb0526ba0b5b34d9\%40sessionmgr4004\&vid=4\&hid $=4101$.

Butler, R. N. (2005). Ageism: Looking back over my shoulder. Generations, 29(3), 8486.

Damron-Rodrigez, J., Fundenburk, B., Lee, M., \& Solomon, D. H. (2004). Undergraduate knowledge of aging: A comparative study of biopsychosocial content. Gerontology \& Geriatrics Education, 25(1), 53-71.

Dremelj, P. (2003). Sorodstvene vezi kot vir socialne opore posameznikov. Družboslovne razprave, 19(43), 149-170.

Fraboni, M., Saltstone, R., \& Hughes, S. (1990). The Fraboni scale of ageism (FSA): An attempt at a more precise measure of ageism. Canadian Journal on Aging, 9(1), 5666.

Gellis, Z. D., Sherman, S., \& Lawrence, F. (2003). First year graduate social work students' knowledge of an attitude toward older adults. Educational Gerontology, 29, 1-16.

Gilbert, C. N., \& Ricketts, K. G. (2008). Children's attitudes toward older adults and aging: A synthesis of research. Educational Gerontology, 34(7), 570-586. Retrieved form http://web.b.ebscohost.com.ezproxy.lib.ukm.si/ehost/pdfviewer/ 


\section{Acta Educationis Generalis \\ volume 8,2018 , issue 1}

pdfviewer?sid=98ddf67f-aa7b-4767-872f-28bcd74f41ff\%40sessionmgr198\&vid= $35 \&$ hid $=124$.

Goriup, J. (2014). Vpliv globalizacije na družbo znanja in medgeneracijsko učenje. Revija za ekonomske in poslovne vede, 1(1), 83-101.

Goriup, J., Čagran, B., \& Krošl, K. (2015). Education of older people for combating their loneliness. Acta Technologica Dubnicae, 5(1), 21-36. doi: 10.1515/atd-20150030

Hagestad, G. O., \& Uhlenberg, P. (2006). Should we be concerned about age segragation? Some Theoretical and Empirical Exploration. Research in Aging, 28(6), 638-653.

Harris, L., \& Dollinger, S. (2001). Participation in a course of aging: Knowledge, attitudes and anxiety about aging in oneself and others. Educational Gerontology, 27(8), 657-667.

Hvalič Touzery, S. (2009). Prebivalstvo Slovenije se stara. Kakovostna starost, 9(2), 5457.

Kaya, G., Candan, S., Avşar-Tuncaya, A., Hakverdi-Cana, M., Cana, D., \& Pekbayb, C. (2014). Aging education in elementary textbooks. Procedia - Social and Behavioral Sciences, 116, 3030-3037. Retrieved from http://www.sciencedirect.com/science/article/pii/S1877042814007198

Kalavar, J. (2001). Examining ageism: Do male and female college student differ. Educational Gerontology, 27(6), 506-513.

Knapp, J. L., \& Stubblefield, P. (2000). Changing students' perceptions of aging: The impact o fan intergenerational service learning course. Educational Gerontology, 26(7), 611-621.

Kroutil, J. A., \& Wasyliw, Z. (2002). Infusing Gerontology into grades 7-12 Social Studies curricula. Gerontologist, 42(3), 387-391.

Lasher, K. P., \& Faulkender, P. J. (1993). Measurement of aging anxiety: development of anxiety about aging scale. International Journal of Aging and Human Development, 37(4), 247-259.

McGuire, S. (1993). Promoting positive attitudes through aging education: a study with preschool children. Gerontology \& Geriatrics Education, 13(4), 3-12.

McGuire, S., \& Mefford, L. (2007). Growing up and growing older. The Journal of School Nursing, 23(2), 80-85.

Meshel, D. S., \& McGlynn, R. P. (2004). Intergenerational contact, attitudes, and stereotypes of adolescents and older people. Educational Gerontology, 30(6), 457479.

O'Hanlon, A. M., \& Brookover, B. C. (2002). Assessing changes in attitudes about aging: Personal reflections and a standardized measure. Educational Gerontology, 28(8), 711-725.

O'Hanlon, A. M., Camp, C., \& Osofsky, H. (1993). Knowledge of and attitudes toward aging in young, middle-aged and older college student: A comparison of two measures of knowledge of aging. Educational Gerontology, 19(8), 753-766.

Olson, M. D. (2007). Gerontology content in MSW curricula and student attitudes toward older adults. Gerontology Content in MSW Curricula and Student Attitudes toward Older Adults, 33(11), 981-994. Retrieved from http://web.b.ebscohost.com.ezproxy.lib.ukm.si/ehost/pdfviewer/pdfviewer?sid=98d df67f-aa7b-4767-872f-28bcd74f41ff\%40sessionmgr198\&vid=30\&hid=124 


\section{Acta Educationis Generalis \\ volume 8,2018 , issue 1}

Palmore, E. B. (1977). Facts on aging: A short quiz. The Gerontologist, 14(4), 315-320.

Palmore, E. B. (1998). The facts on aging quiz. New York: Springer.

Pečjak, V. (2007). Psihologija staranja. Ljubljana: samozaložba.

Randler, C., Vollmer, C., Wilhelm, D., Flessner, M., \& Hummel, E. (2014). Attitudes towards the elderly among German adolescents. Educational Gerontology, 40(3), 230-238. Retrieved from http://web.a.ebscohost.com.ezproxy.lib.ukm.si/ehost/ pdfviewer/pdfviewer?vid=4\&sid=3e113d34-382e-4bc5-be3b59449a5f08f3\%40sessionmgr4004\&hid=4106.

Rener, T. (1997). Rastoča manjšina: problem negovalnega dela. Družboslovne razprave, 13(24-25), 40-48.

Rupp, D., Vodanovich, S., \& Crede, M. (2005). The multidimensional nature of Ageism: construct validity and group differences. The Journal of Social Psychology, 145(3), 335-362.

Schirrmacher, F. (2007). Zarota mentuzalemov. Ljubljana: Vale - Novak.

Scott, T., Minichiello, V., \& Browning, C. (1998). Secondary school students' knowledge of and attitudes towards older people: Does an education intervention programme make a difference? Ageing and Society, 18(2), 167-183.

Stuart-Hamilton, I., \& Mahoney, B. (2003). The effects of aging awareness training knowledge of and attitudes toward older adults. Educational Gerontology, 29(3), 251-260.

United Nations. (2015). Profiles of Aging 2015. Population Division. Retrieved from http://esa.un.org/unpd/popdev/Profilesofageing2015/index.html

Van Dusen, V. J., \& Weawer, R. R. (2009). Undergraduate students' perceptions and behaviors related to the aged and to aging processes. Educational Gerontology, 35(4), 342-357.

Vygotski, L. S. (1978). Mind in society. Cambridge: Harvard University Press.

Ward, R. A. (1979). The Aging Experience: An Introduction of Social Gerontology. New York: Lippincott.

Wisdom, N. M., Connor, D. R., Hogan, L. R., \& Callahan, J. L. (2014). The relationship of anxiety and beliefs toward aging and ageism. Journal of Scientific Psychology, 10-21. Retrieved from http://www.psyencelab.com/images/Anxiety_and_Ageism. pdf 